\title{
Review article: \\ THE ROLE OF ELTROMBOPAG AND ROMIPLOSTIM AS THE THROMBOPOIETIN RECEPTOR AGONIST (TPO-RA) IN TREATMENT OF IDIOPATHIC THROMBOCYTOPENIC PURPURA (ITP): WHAT IS TPO-RA, WHEN TPO-RA IS USED AND HOW TO TAKE TPO-RA?
}

\author{
Jefri Pratama Susanto \\ Brawijaya University, Faculty of Medicine, Malang, Indonesia
}

\begin{abstract}
ABSTRAK
Idiopathic Thrombocytopenic Purpura (ITP) merupakan penyakit autoimun yang ditandai dengan trombositopenia akibat destruksi trombosit yang berlebihan. Namun pada beberapa kasus didapatkan baik destruksi trombosit dan penurunan kadar trombopoietin. Oleh karena itu muncul paradigm baru dalam penatalaksanaan ITP yaitu dengan meningkatkan kadar trombopoietin dengan menggunakan eltrombopag atau romiplostim sebagai agonis reseptor trombopoietin. Eltrombopag diberikan secara per oral sedangkan romiplostim diberikan secara subkutan atau intravena dan dosis kedua obat disesuaikan berdasarkan jumlah hitung trombosit. Baik eltrombopag dan romiplostim dapat digunakan pada kasus ITP yang memberikan respon minimal terhadap glukokortikoid, immunoglobulin intravena ataupun splenektomi. (FMI 2015;51:203-207)
\end{abstract}

Kata Kunci: Agonis reseptor trombopoietin, eltrombopag, ITP, Romiplostim, trombopoietin.

\begin{abstract}
Idiopathic thrombocytopenic purpura is a autoimmune disease characterized thrombocytopenia casued by excessive platelet destruction. However, both platelet destruction and reduced thrombopoietin level are occurred in some cases. Therefore, new management of ITP is emerged which target is to increase platelet production rate via eltrombopag or romiplostim as the thrombopoietin receptor agonist (TPO-RA). Eltrombopag is given orally while romiplostim is given subcutaneously or intravenously and dose adjustment is depend on platelet count. Both eltrombopag and romiplostim is indicated in minimal response glucocorticoid or intravenous immunoglobulin or splenetomy treatment.(FMI 2015;51:203-207)
\end{abstract}

Keywords: Thrombopoietin receptor agonist (TPO-RA), thrombopoietin, eltrombopag, ITP, romiplostim.

Correspondence: Jefri Pratama Susanto, Faculty of Medicine, Brawijaya University, Malang, Indonesia. Phone: 08123043514/087859298055. Email: j3ff_12y@yahoo.com

\section{INTRODUCTION}

Idiopathic Thrombocytopenic Purpura (ITP) is an autoimmune disease characterized by transient or persistent thrombocytopenia (<100x109/L). The term "newly diagnosed ITP" is used to explain all ITP cases, which are just diagnosed. Persistent ITP is defined as ITP lasting from 3 to 12 months since the first diagnosis, and chronic ITP is defined as ITP lasting more than 12 months. Secondary ITP includes all immune mediated thrombocytopenia except primary ITP (Cheng, 2012).

For many years, the pathophysiology of ITP is caused by excessive platelet destruction and clearance and this is auto reactive antibody mediated process against platelet glycoprotein. Even though platelet life span often reduced dramatically, in several patients, this platelet life span is slightly reduced and platelet production rate is suboptimal. Overall, platelet production rate is decreased in $40 \%$ patient of ITP.
Based on this findings, autoantibody against platelet glycoprotein is found to disturb megakaryocytes maturation, resulting in decreased platelet production. More over, most megakaryocytes shows ultra structural features of apoptosis or para-apoptosis and this morphological changes can be proven in culture megakaryocytes wtih ITP plasma. In vitro study, antibody that attack platelet glycoprotein (GP) Ib-IX-V might cause thrombocytopenia via megakaryopoiesis inhibition and pro-thrombocytes formation. (Stasi et al, 2011).

Most ITP treatments are aimed to reduce autoantibody production and or to slow down opsonized platelet, which in the end will be engulfed by macrophage. Based on the pathophysiology mentioned above, some of patients of ITP have platelet production disturbance rather than excessive platelet destruction (Stasi et al, 2011). Therefore, this review article will discuss about ITP management focus on thrombopoietin receptor agonist (TPO-R) which are eltrombopag and romi- 
plostim, what are they, when they are used and how to take these drugs.

\section{THROMBOPOIETIN RECEPTOR AGONIST (TPO-R)}

Thrombopoietin is a humoral regulator of platelet production. Endogenous thrombopoietin is produced mainly in liver, bind specifically and activates thrombopoietin receptor, which is located on megakaryocytes membrane and induces cytoplasmic signaling to produce platelet (Imbach and Crowther, 2011).

Fact has shown that thrombopoietin level in ITP is low and it is not well compensated by the body, resulting in new concept of ITP management by stimulating thrombopoietin receptor exogenously. First trial is by using recombinant thrombopoietin, but this trial is stopped due autoantibody associated thrombocytopenia against endogenous thrombopoietin (Imbach and Crowther, 2011). There fore, the development of second generation of thrombopoietin receptor agonist is started. Structurally, this second generation of TPO-R is different with thrombopoietin, so there will be no autoantibody formed. Romiplostim is a syntethic fusion protein with four peptides consist of 14 amino acid residue connected to an $\mathrm{IgG}$ fragment $\mathrm{Fc}$, this bond form a "peptibody" (Figure 1A) (Imbach and Crowther, 2011). Romiplostim binds to thrombopoietin receptor and activates intercellular signaling pathway (JAK_STAT pathway and MAP kinase), where this pathway will stimulate platelet production (Figure 1C). Eltrombopag is a small non-peptide molecule bound to trans membrane of thrombopoietin receptor and then activates the same intercellular pathway as activated by romiplostim (Figure 1B and Figure 1C) (Imbach and Crowther, 2011).

\section{ELTROMBOPAG}

Eltrombopag is a non-peptide thrombopoietin receptor agonist which is administered orally in tablet. In a preclinic study, eltrombopag stimulates megakaryocytes differentiation and proliferation by stimulation in thrombopoietin receptor and this drug is dose-dependant (Stasi et al, 2011). Mechanism action of eltrombopag to activate thrombopoietin receptor is different with romiplastim. Eltrombopag interacts with the thrombopoietin receptor at a binding site distant from that of thrmobopoietin and appears to initiate signal transduction by a mechanism different from that of endogenous thrombopoietin. There fore, eltrombopag and endogenous thrombopoietin will not bind at the same site, so competitive bind will not happen, in fact these can give synergistic effect (Stasi et al, 2011).

Recommendation for eltrombopag initial dose to most patients is $50 \mathrm{mg} /$ day and given orally. Dose adjustment is based on platelet count (maximal dose is $75 \mathrm{mg} /$ day or minimal dose $25 \mathrm{mg} /$ day). This dose adjustment can be seen in table 1 (Ashariati, Sedana, Bintoro and Diansyah, 2014). Patient with hepatic dysfunction and Asians should start the drug with $25 \mathrm{mg} /$ day. Eltrombopag should be taken 1-2 hours after meals due to its interaction with food. Tis drug should not be taken within 4 hours after taking antacid (Imbach and Crowther, 2011). Increase in platelet count can be sustained after 8 days using the drug and then decrease after 12 days discontinuation of the drug. Half time of the drug is approximately 12 hours (Siegal et al, 2013).

\section{ROMIPLOSTIM}

Romiplostim is a recombinant protein also known as the "peptibody". Romiplostim bind and activates thrombopoietin receptor through a similar mechanism as endogenous thrombopoietin via signaling pathway activation such as tyrosine phosphorylation janus kinase 2 and signal transducer and activator of transcription 5 (STAT). Romiplostim increase megakaryocytes maturation in vitro and it is a competitive agonist with thrombopoietin to bind with human thrombopoietin receptor in vitro (Stasi et al, 2011). Romiplastim can be given intravenously or subcutaneously. The platelet count escalation can be achieved within 5-8 days and then back to baseline on 28 days (SIegal et al, 2013).

Recommendation initial dose of romiplostim is 11 $\mathrm{ug} / \mathrm{kgBB}$ given subcutaneously, once a week with dose adjustment based on platelet count. This dose adjustment can be seen in table 2 (Bussel et al, 2009). The therapeutic dose is approximately 3-4 ? $/ \mathrm{kgBB}$ with maximal dose is 10 ?g/kgBB. Romiplostim is available in 250-?g and 500-?g vials as a lyophilized powder.

\section{THROMBOPOIETIN RECEPTOR AGONIST INDICATION}

The goal of ITP management is to maintain platelet count in which can minimize the bleeding tendency. Observation alone is should be done when no bleeding or mild bleeding occurs while thrombocyte count is $30 \mathrm{x}$ $\mathrm{x} 109 / \mathrm{L}$ in adult. Management in patient with low platelet count is indicated if only active bleeding happens or platelet count is very low $(<10 \times 109 / \mathrm{L})$. 


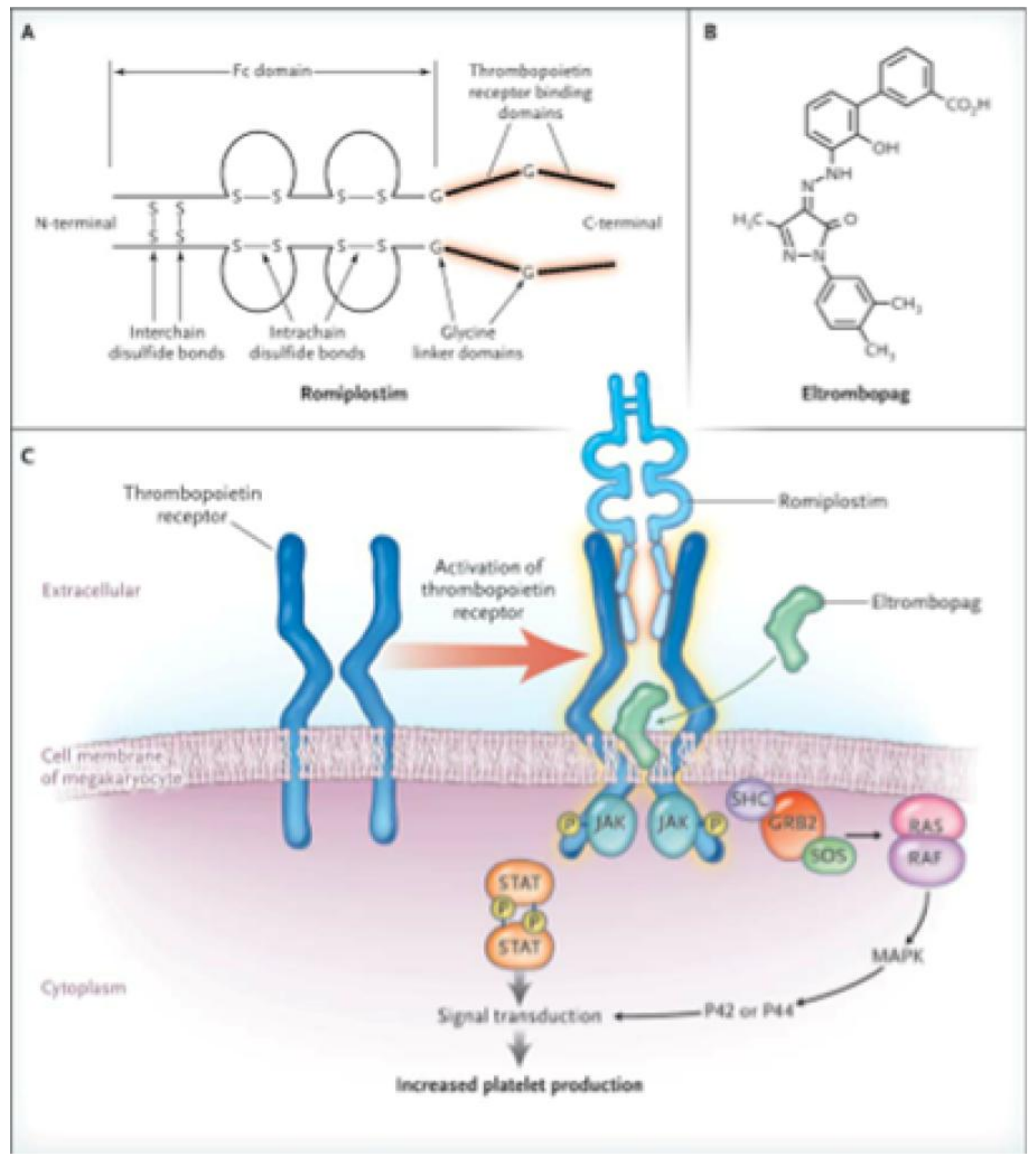

Figure 1. Romiplostim and Eltrombopag Structure and Its Intercellular Pathway. Panel A shows chemical structure of romiplostim. Panel B shows chemical structure of Eltrombopag. Panel C shows mechanism action of Romiplostim and Eltrombopag. GRB2 denotes growth factor receptor-binding protein 2, JAK Janus kinase, MAPK mitogen-activated protein kinase, P phosphorylation, RAF rapidly accelerated fibrosarcoma kinase, RAS rat sarcoma GTPase, SHC Src homology colla- gen protein, and STAT signal transducer and activator of transcription (Imbach and Crowther, 2011) 
Table 1. Eltrombopag dose adjustment (Ashariati, Sedana, Bintoro and Diansyah, 2014).

\begin{tabular}{|c|c|}
\hline Platelet Count & Dose Adjustment and Response \\
\hline $\begin{array}{c}<50 \times 10^{9} / \mathrm{L} \text { after taking eltrombopag for minimal } 2 \\
\text { weeks }\end{array}$ & $\begin{array}{l}\text { Increase daily dose by } 25 \mathrm{mg} \text { to a maximum of } 75 \mathrm{mg} \\
\text { daily. For patients taking } 12.5 \mathrm{mg} \text { once daily, increase } \\
\text { the dose to } 25 \mathrm{mg} \text { daily before increasing the dose } \\
\text { amount by } 25 \mathrm{mg} \text {. }\end{array}$ \\
\hline $200-400 \times 10^{9} / \mathrm{L}$ at anytime & $\begin{array}{l}\text { Decrease the daily dose by } 25 \mathrm{mg} \text {. Wait } 2 \text { weeks to } \\
\text { assess the effects of any dose adjustments. }\end{array}$ \\
\hline$>400 \times 10^{9} / \mathrm{L}$ & $\begin{array}{l}\text { Stop eltrombopag; increase the frequency of platelet } \\
\text { monitoring to twice weekly. Once the platelet count is } \\
\text { less than } 150 \times 10^{9} / \mathrm{L} \text {, reinstate therapy at a daily dose } \\
\text { reduced by } 25 \mathrm{mg} \text {. For patients taking } 25 \mathrm{mg} \text { once } \\
\text { daily, reinitiate therapy at } 12.5 \mathrm{mg} \text { daily. }\end{array}$ \\
\hline$>400 \times 10^{9} / \mathrm{L}$ after 2 weeks with minimal dose & Permanently discontinue eltrombopag. \\
\hline
\end{tabular}

Table 2. Romiplostim Dose Adjustment (Bussel et al, 2009)

\begin{tabular}{|c|c|}
\hline Platelet Count & Dose Adjustment and Response \\
\hline$\leq 10 \times 10^{9} / \mathrm{L}$ & $\begin{array}{l}\text { Dose increased by } 2 \mathrm{~g} / \mathrm{kgBB} \text { every week when platelet } \\
\text { counts were }<=10 \times 10^{9} / \mathrm{L} \text { (Dose could be increased } \\
\text { every week.) }\end{array}$ \\
\hline $10-50 \times 10^{9} / \mathrm{L}$ & $\begin{array}{l}\text { Dose increased by } 2 \mathrm{~g} / \mathrm{kgBB} \text { after } 2 \text { consecutive } \\
\text { weeks of platelet counts }<50 \times 10^{9} / \mathrm{L} \text {. (Dose could be } \\
\text { increased every } 2 \text { weeks.) }\end{array}$ \\
\hline $50-250 \times 10^{9} / \mathrm{L}$ & $\begin{array}{l}\text { Dose could be adjusted by } 1 \mathrm{~g} / \mathrm{kgBB} \text { (increased or } \\
\text { decreased) at the investigator's discretion, no more } \\
\text { frequently than every } 2 \text { weeks. The maximum dose was } \\
10 \mathrm{~g} / \mathrm{kgBB} \text { weekly. }\end{array}$ \\
\hline $250-400 \times 10^{9} / \mathrm{L}$ & $\begin{array}{l}\text { Dose reduced by } 1 \mathrm{~g} / \mathrm{kgBB} \text { after } 2 \text { consecutive weeks } \\
\text { of platelet counts in this range. (Dose could be reduced } \\
\text { every } 2 \text { weeks.) }\end{array}$ \\
\hline$\geq 400 \times 10^{9} / \mathrm{L}$ & $\begin{array}{l}\text { Next scheduled dose was held. On the next scheduled } \\
\text { dosing day that the platelet count was }<250 \times 10^{9} / \mathrm{L} \text {, the } \\
\text { dose was reduced by } 1 \mathrm{~g} / \mathrm{kgBB}\end{array}$ \\
\hline
\end{tabular}

First line treatment of ITP generally is glucocorticoid, intravenous immunoglobulin or both. The only second line treatment that can sustain platelet count escalation is splenectomy. Rituximab is used widely as the second line treatment, even though the mean duration of response is 10,5 months. Romiplostim and eltrombopag have been approved by the FDA for chronic ITP with minimal response to glucocorticoid, intravenous im- muneglobulin or splenectomy. Clinically, both romiplostim or eltrombopag is used in chronic or persistent ITP and ongoing bleeding with or without previous splenectomy and one or more courses of rituximab. Since this thrombopoietin receptor agonist pass through placenta, so the uses of this drug in pregnancy is prohibited (Imbach and Crowther, 2011) 


\section{CONCLUSION}

The new paradigm of ITP pathophysiology, which is reduced thrombopoietin level, has opened a new perspective to the dramatic advance of ITP management. Eltrombopag acts through a different pathway as endogenous thrombopietin while romi-plostim acts the same as endogenous thrombopietin. Eltrombopag is administred orally and can be started with $25 \mathrm{mg} / \mathrm{day}$. Romiplostim is administered sub-cutaneously or intravenously and the starting dose is $2 \mathrm{ug} / \mathrm{kgBB}$ every week. Both eltrombopag and romi-plostim as the thrombopoietin receptor agonist (TPO-RA) can be used in chronic ITP with minimal response to first or second line treatment of ITP.

\section{REFERENCES}

Asharianti, A. Sedana, MP. Bintoro, UY. Diansyah, MN. Naskah Lengkap Surabaya Hematologi Onkologi Medik Update-XII (SURABAYA HOM UPDATE-
XII) Toward Brighter Management of Hemato Oncology in Asian Region From Bench to Clinical Practice. Fakultas Kedokteran Universitas Airlangga Surabaya- RSUD Dr. Soetomo. 2014: page 16.

Bussel, JB. Kuter, DJ. Pullarkat, V, et al. Safety and efficacy of long-term treatment with romiplostim in thrombocytopenic patients with chronic ITP. Blood. 2009; 113:2161-2171)

Cheng, G. Eltrombopag, a thrombopoietin- receptor agonist in the treatment of adult chronic immune thrombocytopenia: a review of the efficacy and safety profile. her Adv Hematol (2012) 3(3) 155-164

Imbach, P. Crowther, M. Thrombopoietin-Receptor Agonists for Primary Immune Thrombocytopenia. N Engl J Med 2011;365:734-41.

Siegal, D. Crowther, M. Cuker, A. Thrombopoietin Receptor Agonists in Primary ITP. Semin Hematol 2013; 50(0 1): S18-S21.

Stasi, R. Rhodes, E. Benjamin, R. Buyck, et al. The Emergence of Thrombopoietin Receptor Agonists as a Novel Treatment for Immune Thrombocytopenia. European Ocology \& Haematology 2011;7(1):63-70 